\title{
THE MODERATING ROLE OF SOCIAL CLASS: EFFECT OF BRAND SERVICE SCAPES ON LOYALTY
}

\author{
Atif Shahab Butt ${ }^{1}$ \\ Assistant Professor, Iqra University, Main Campus, Karachi. \\ DR. Irfan Hameed ${ }^{2}$ \\ Knowledge Unit Leader (Business), Iqra University, Main Campus, Karachi. \\ DR. Imran Hameed ${ }^{3}$ \\ Teaching Faculty, University Of Lahore, Lahore.
}

\begin{abstract}
Purpose: In this study, the impact of Services cape on Loyalty has been studied in the presence of Social Class as a moderating variable.

Methodology: The probability based systematic random sampling technique is used to collect the data through a self-administered survey to test the gained hypothesis from 308 respondents living in upper, middle and lower classes. A structured questionnaire was approved of actual information from the respondents to support the collection gained. The conceptual development of costumer's loyalty measurement scale proposed by McMullan (2005) was adopted for analyzing the loyalty and for computing the services cape of the restaurant the instrument proposed by Hightower (2010) was acquired. SPSS and AMOS were being used to check the questionnaire. The instruments reliability was checked by using confirmatory factor analysis (CFA) and composite reliability test. SEM (structural equation modelling) through AMOS was used to examine the data. Moderation and moderation steps were analyzed by using orthogonalization and 5000 bootstrapping samples, SPSS MACRO developed by preacher \& Hays to check the moderation.

Findings: Ambient $=0.71$, social $=0.75$, design $=0.72$ and customer loyalty 0.70 is the outcome of CFA. The positive relation of the loyalty of restaurant with ambiance, social dimension and design dimension of services cape was tested as the first three hypothesis using linear regression. Moreover, the analyzed result of hypothesis 4, 5 and 6 indicated the outcome that social class effects while picking the restaurant.

Originality/Value: By this research, the buying and spending pattern of consumers in Pakistan and the factors that influence the repeat selection of the restaurant in presence of their social class of the target market has been brought into attention.
\end{abstract}

Key Words: Services cape, Loyalty, Services Marketing, Social Dimension, Design Dimension, Ambiance, Physical Environment.

* The material presented by the author does not necessarily portray the viewpoint of the editors and the management of the Institute of Business \& Technology (IBT)

1. Atif Shahab Butt

: atif@iqra.edu.pk

2. DR. Irfan Hameed

: irfan_h144@yahoo.com

3. DR. Imran Hameed

: im_hameed@hotmail.com

(C) IBT-JBS is published by the Institute of Business and Technology (IBT). Main Ibrahim Hydri Road, Korangi Creek, Karachi-75190, Pakistan. 


\section{INTRODUCTION}

As far as service management is concerned it is one of the important aspects of bringing loyalty into the customer base (Grönroos, 1987). The effect of the atmosphere, physical design and décor on consumers has been acknowledged by the marketer that is why marketer continuously builds, plan change and control the physical surrounding of the place where they are serving to their customers (Normann, 1991).The ability of this physical setting is to create an image of the place such as hotels, restaurants as a prestigious service serving place to the customers, because the service is usually shaped and consumed at the same time. The customers at the restaurant have to wait and consume the total service at the same place.

Service quality is vital for the satisfaction of the target audience in the current era of business, so it is important for the company to understand how customers perceive quality with reference to the physical environment of the place where they are purchasing. This servicescape leads to the satisfaction and post purchase behavior (Gronroos, 1984). If customers get tempting servicescape they may get loyal and repeatedly come to the same place and refer that place to others that creates a positive buzz among the potential customers. The restaurants now a day's try to take full advantage of the physical stimuli that compose servicescapes by adding the ambiance, design dimension and the social dimension in to the restaurant in order to maximize the consumer's experience that leads to loyalty.

Right now there are so many factors that impact the customers preferences when selecting a restaurant for instance; the physical dimensions such as artifacts, air, equipment, furnishings, layout, music, noise, odor, quality, space/function, temperature, signs, symbols, signage, style of décor; the social dimensions such as customers, displayed emotions of others, design dimension, employees and social density, may lead to frequently visiting of the same restaurant. However on the basis of different social classes' different dimensions of Servicescape may stimulate differently.

Whenever consumers have to take any purchase decisions the distinct behavioral patterns are observed, but when we study the impact of social class on the behavior the consumers of Pakistan the key determinants are income, wealth and education which can impact the purchase decision specifically when they have to select a restaurant. On the other hand the servicescape of the restaurant is one of the major stimulation in order to select a restaurant, consumers belonging to different social classes choose restaurant on the basis of different stimulis.

For consumers belonging to the upper class the physical dimension, social dimension and design dimension is the priority because these customers are not price conscious customers, but are in fact service conscious customers. Customers require prompt service in a peaceful environment with an invigorating ambiance. The middle and working class price is one of the major concerns along with an average quality servicescape. However, for the lower class the main concern is the price no matter what the servicescape and the ambiance of the restaurant. The physical evidence of the service can only be experienced through the design dimension, as service has the variability characteristic so if it varies when visiting a restaurant, it may create a dissonance (Shin \& Elliott, 2001).

Therefore, in order to comprehend how consumers actually assess service brands researcher must consider the tangibility characteristic of the service provider in-terms of ambiance and physical dimension of the service since the physical settings influence the loyalty based on the service experience, aroused feelings, satisfaction and service attitude.

Likewise, a major challenge for marketers who provide service is to take up unique and novel strategies based of the nature of their service and changing consumer behavior of the target audience. As per the nature of the service offering variable, purchase decisions making, 
consumption overall experiences and post-purchase check and evaluation of services can often cause issue to service consumers (Grace \& O'Cass, 2001).

It is important for marketer to know what kind of problems customers face when selecting restaurants, because service is an experience rather than a physical entity (Martin, 1999).

\section{PROBLEM STATEMENT}

The importance of the servicescape and the physical settings within the guest experience are necessary when setting up a restaurant.

Consumers belonging to different social classes and cultures proceed differently when selecting restaurant in-terms of service encounter and physical evidence and surrounding of the selected place. That is why it is a necessary to continuously change, enhance and upgrade the atmosphere of restaurant in order to enhance the brand experience of their customers.

So the problem statement which is under consideration is "To identify the impact of Servicescapes on the culture of identified population of Pakistan with reference to social classes"

\section{HYPOTHESIS DEVELOPMENT}

The atmospheric effect of the servicescape, specifically the ambiance of the restaurant has a strong expectant effect on auspicious response from customer side (Uhrich \& Benkenstein, 2011). A better placed service can contribute towards the satisfaction of the target market resultant to a strategic response in-term of customer's loyalty (Izogo \& Ogba, 2014). A strong bounding can be made called as lasting relationship between customer and service provider resultant in building a social capital for the service provider (Jones \& Taylor, 2012).

\section{H1: Ambiance of the restaurant has a positive impact on customer's loyalty.}

The phenomena's of service consumption have immensely changed in-terms of format and consumer behavior, target audiences are not only interested in the ambiance, they love to avail the prompt response from the internal customers (Koul \&Mishra, 2013). Service providers can modify the services as a tool to high customer retention rates and minimize the churn between attention and retention to gain the satisfaction but to heighten the loyalty of the customers (Coelho \& Henseler, 2009). Marketer has to manage the social dimension of servicescape to an extant to prove them to become loyal customers to increase the life time value for them (Harris \& Ezeh, 2007). Within the servicescape of the restaurant it's not only the social dimension and ambiance which play a vital role to make customer loyal

\section{H2: Social dimension of the restaurant has a positive impact on customer's loyalty.}

Visual elements and the aesthetical appeal communicate about the organizational approach towards the way it's doing things (Harris \& Ezeh, 2007). Different customers conceptualize differently from the servicescape, throughout the whole service experience, indicates that the overall shopping experience can never be controlled the service provider, so it's important for the marketer to understand the social ambient and design dimension to great them properly (Walter \& Edvardsson, 2012). On the other hand discuss the servicescape of the restaurant and its impact on the loyalty and purchasing pattern, we cannot overlook the implication of social class to become more or less loyal customers. Because loyalty is highly dependent of the purchasing power and social class is highly dependent on the income of the target market so loyalty and social class has a close relation 


\section{H3: Design dimension of the restaurant has a positive impact on customer's loyalty.}

Variation in attitude, motivation, perception, personality, lifestyle and value orientation are associated to different social classes, it has been determined that social class is momentous to predict the evaluation criteria of selection of any good or a service (Williams. 2002). Beside this customer expectation and perceived quality also foster customers satisfaction and loyalty. Loyalty is also determined as customer's commitment towards buying same brand again and again on the basis of satisfaction (Kursunluoglu, 2014). Moreover service provider can alter or amend the servicescape and internal settings to complement the understandings and perceptual variations of its target market to keep them more involved into its restaurant or physical location where the service is been provided (Mathews, Bonn \& Snepenger, 2009). Same ways different variables within the servicescape have their own effect on loyalty while studying the social class as a moderating variable.

H4: The relationship between ambiance of restaurant and customer loyalty is moderated by social class such that the relationship would be stronger for upper and middle classes as compared to lower class.

One of the most important paradigms in service marketing is loyalty with its effect on the purchasing pattern of the buyers; truly the loyalty panders the repeat purchase to attain the financial objectives of any business (Caruana, 2000). Though the customers judge the service quality based on the functional value, customers also perceive social dimension as a reputational aspect of service quality during the shopping experience (Hsin-Hui $\mathrm{Hu}, 2010$ ). Moreover markets are tend to know the social classes of its target market within a society because consumers belonging to the same social class are inclined towards showing the same behavior when taking a purchase decision (Kotler \&Keller, 2014).

H5: The relationship between social dimension of restaurant and customer loyalty is moderated by social class such that the relationship would be stronger for upper and middle classes as compared to lower class.

It's important for the marketer to understand how the overall service consumption is been experienced. This is extremely important since the shopping experience is highly dependent upon the design dimension of the servicescape (Walter, Edvardsson, \& Ostrom, 2010). Subsequently the perceptual process like selective retention also plays a vital role when taking a purchase decision (Williams, 2002), So the loyalty status may vary from social class to social class because the higher income group or upper classes may be more loyal on the basis of their previous shopping experience, as lower and middle income group has less purchasing power so they may act like brand switchers.

H6: The relationship between design dimension of restaurant and customer loyalty is moderated by social class such that the relationship would be stronger for upper and middle classes as compared to lower class. 


\section{LITERATURE REVIEW}

\section{Service Quality in Restaurant}

Scholars like (Anderson et al., 1994) mentioned that the service quality improvement in resultant satisfaction and lead towards repeat purchase. Scholars also pointed out that service quality is a central force to customer satisfaction (Andaleeb \& Conway, 2006; W.G. Kim et al., 2009; H.S. Kim et al., 2009) so service quality is been viewed as a source of service quality differentiation. Behavioral intent and satisfaction is been effected positively by the service quality (Hansen \& Bush, 1999; W.G. Kim et al., 2009; H.S. Kim et al., 2009; Liu \& Jang, 2009). Moreover quality of the service of a restaurant is a result of the overall dining experience of the customer. Adding more in to this subject (Ryu \& Han, 2009) has presented three more dimensions of quality of a restaurant in-terms of (predictors: food, service, and physical environment), price (moderator), and satisfaction and behavioral intention (criterion), research emphasized that food, service and physical environment give a significant effect to customer's intention to repeatedly visiting to the same restaurant. Service quality of a restaurant is also been debated by authors like (Cronin \& Taylor, 1992) observed and measured the concept of service quality with customer satisfaction and purchase intent, they found out that the service quality is the originator of customer satisfaction, though the satisfaction is not been led by the service quality. (Anderson et al.,1994) also rationalized that the satisfaction of the target market can be improved when a quality service is been offered to the customers and it enhances the customer life time value (CLV) that is why the repeat purchase of loyalty is a reflection of good quality service. At the start of 1980, this topic of service quality start attracting the researchers and scholars so a scholar (Parasuraman et al., 1985) expounded the service quality as a variance between the perceptions of the service experience and customer's expectations.

\section{DECISION-MAKING MODEL OF IPA, IPGA AND DEMATEL ANALYSIS}

Importance- Performance Analysis (IPA) is a technique which was used previously inorder to gauge the service quality, IPA was applied by (Marr, 1986) for measuring the customer oriented service quality and attributes and converted into a "importanceperformance standard coordinate plane" to comprehend the pros and cons of all service quality attributes. IPA can be used to strategize the service and take strategic decision on service quality improvement and service quality differentiation (Hansen \& Bush, 1999). While observing the limitations of IPA, (Chenga, Chena, Hsua \& Yuan Hub, 2012) presented a two phase model of decision making while going for a find dine or selection of a restaurant, they discussed that the traditional IPA model has some limitations and cant not connect the gap between service quality attributes, so in-order to fill this gape scholars came up with IPGA model and DEMATEL analysis. Moreover the Importance-Performance \& Gap Analysis (IPGA) can narrow down the service quality gaps. In addition to

this study, to evaluate and resolve the complicated and intertwined problem group Decisionmaking trial and evaluation laboratory (DEMATEL) is been used (Wu et al., 2010; Shieh et al., 2010), this approach is widely been used to find the key success factors in the industries like airline industry, emergency management, web-advertising, auditing and risk control , enterprise resource planning environment, , hospital service quality management (Liou et al., 2007; Tzeng et al., 2007; Shieh et al., 2010; Wu et al., 2010; Tsai and Hsu, 2010; Wei et al., 2010; Chang and Cheng, 2011; Wu and Tsai, 2011; Zhou et al., 2011; Lin et al., 2012; 
Tsai et al., 2013), this also caters to the performance evaluation of employees, and gauges the risks of failures.

\section{Service Acquisition: A Complex Decision}

The potential customer faces doubt with respect to services, since services are rather intangible and typically used after purchasing; therefore they are interested in decreasing the irregularities of information by obtaining it beforehand (Reimer \& Kuehn, 2005). Searching information is difficult and intricate due to the deficient market transparency. Hence a customer who doesn't have the complete information about a desired service is likely to rely on individual sources especially the feedback recommendations of peers and friends and those who don't know then focus on certain quality signals (Reimer \& Kuehn, 2005). The media of a restaurant often features their cuisine or famous chefs, but it doesn't cover anything about the frontline where the service encounter takes place which are the actual vital elements for the guests' well-being, gratification and loyalty (Walter, 2008).

\section{Servicescape and Physical Settings}

Servicescape has been broadly used term to explain the physical ambiance surroundings of a service providing company. A problem in past studies is the inadequate operationalization of the servicescape as some magnitudes of the physical surrounding have not been included (Reimer \& Kuehn, 2005).

Apart from the physical environment and servicescape, the other aspects are about people and hospitality and an important consideration is how a host/ employee interact with guests and how they can experience a totally unexpected situation (Walter, 2008). Atmospherics is to design buying environments such that it influences the customer's purchase prospect and is conveyed through the sense and thus the particular sense of surrounding are defined in sensory terms i.e. sight, sound, scent and touch (Mari \& Poggesi, 2011).

\section{SERVQUAL}

The model SERVQUAL measures the effects of the servicescape on quality perception and concentrates on 'tangibles' by considering that certain components act as criterion variable of qualities and other dimensions present experience and credibility qualities(Reimer \& Kuehn, 2005). Thus capturing all the directly linked and indirectly influencing variables of the servicescape, as it is not just a single item that leads to perceived quality, but it also effects the customer's evaluation of other aspects defining the seeming service quality in hedonically inspired services. Many ways are used to enhance the dining out experience of the target market. The 'Chez Arvid' case displays one way in which guests can be involved during a restaurant experience (Walter, 2008). In this case the social interaction was more important to guests rather than the physical setting which was less appreciable to them. However, it could be the other way round as well, so that the physical setting enhanced the social factor.

\section{Servicescape; with respect to Ambiance, Design and Social Dimensions}

Restaurant dining provides complex experience that comprises of at least three types of clues: Function (quality of food and service), mechanical (ambience and design features) and humanic (performance, appearance and behavior of employees). A customer's observation to their expectation of service is because of the mechanic clues; however, the humanic clues govern the impact of mechanic clues (Wall \& Berry, 2007). As humanic clues dominate the mechanic clues, restaurants with good service and food, but poor ambience can still be successful, but preferably a restaurant should convey a consistent message to the customers 
(Wall \& Berry, 2007). Even though most marketing literature tends to focus only on the physicality of a place or the stimulus-response characteristics of the place, other disciplines like geography views them in terms of its temporal, spatial, natural and social dimensions as a customer's want for social connectivity and wishes to feel like an insider is sometimes of more importance that the servicescape qualities (Johnstone, 2012). The consumption experience by a consumer is designed by the surrounding social activities, thus the assumption that a consumer's attachment to a place is beyond the physical features or even the service provided (Johnstone, 2012). Changes in the physical environment may impact the social dimensions of a servicescape and could be observed as a positive or a negative change by consumers who are regular visitors as it may no longer reflect the consumer's placeidentity. Consumers tend to find an environment that corresponds to their own personality (Johnstone, 2012). In service organizations the same settings that affect a consumer would also affect the employees (Bitner, 1992). Servicescape can act as an enabler either by adding or obstructing the ability of employees and customers in carrying out their activities thus the planning, designing, refining and managing of the servicescape should include the input for the actual users (i.e. the customers and employees) apart from the managers (Siddiqui \& Tripathi, 2011). Every group is likely to have a diverse opinion, analysis, importance and observation about a certain problem or situation due to their different socioeconomic backgrounds, incompatible objectives and level of obligation to the organization, thus this large number of actors involved in planning provide a better possibility for solving the agenda (Siddiqui \& Tripathi, 2011). The servicescape is suggested to have a categorized factor structure (Hightower, 2010) such that consumers think of it at three different levels at the same time and these are an overall level (of the physical environment), a dimension level (design, ambient and social factors) and a sub dimension level (functional, aesthetic, customers, and employees). E-commerce is expanding at an incredible rate, however most etailors fail to make profits because the majority of online shoppers are very inconsistent, and many of them distrust e-tailing and online payments systems. Therefore e-servicescape involves three main constituents which are namely, aesthetic appeal, layout and functionality, and financial security. This is linked with trust which in turn is associated with a customer's loyalty intentions and this is only possible by the customer's views if incorporated into the design process (Harris \& Goode, 2010).

\section{Servicescape as Marketing Stimuli}

An environment or physical setting acts as the packaging of the service it offers. According to the stimulus-organism-response paradigm (S-O-R), the stimuli is the influence caused by environment on people's evaluation and this in turn influences behavior responses (Mari \& Poggesi, 2011). The behavior responses being avoidance behavior (to avoid that environment) or approach behavior (remain in environment and explore it) are mediated by three emotional states; pleasure/displeasure, arousal/non-arousal and dominance/submissive (Mari \& Poggesi, 2011). A servicescapes naturally soothing element can stimulate relief from mental fatigue and improve customer's health and well-being (Rosenbaum \& Massiah, 2011). Internet has become an important place in daily life, as they dependent on their connection of internet for work school and social networking; therefore there has been a consequential growth in Wireless Fidelity Networks (Wi-Fi). The likelihood of Wi-Fi availability in a restaurant increases the chances of customers returning and they prefer free Wi-Fi over paid models (Cobanoglu, Bilgihan, Nusair, \& Berezina, 2012). McDonalds was the first restaurant to offer free Wi-Fi, however it did not fit the company's mission and they changed it to a model so that people had to buy something to use it. Free Wi-Fi could work better in places where people feel more obligated to buy something (Cobanogluet al., 2012). 
Apart from the servicescape and service encounter that effect the customer, the similar theme of the exterior, interior and even the served food has a positive impact on pleasure level of customers, but its influence on arousal is minimum (Lin \&Mattila, 2010). According to the concept of Gestalt that assumes that living organisms relate to their environment, people generally receive a variety of stimuli from an environment and they organize them cognitively in groups based on their needs and develop general images from it that serve to gratify customer needs (Lin \& Mattila, 2010).

Cleanliness of a servicescape has a strong influence on customer's responses to the extent that it can inhibit a service's failure or even support its recovery as it not only acts as a hygiene factor, but also as a stimulus of purchase intention and perceived service quality (Yavetz \& Gilboa, 2010). There can be a negative effect of dirt and disorder but a clean environment is likely to produce a positive influence on approach behavior and feelings of pleasure, trust and recognized prestige in the customer (Yavetz \& Gilboa, 2010). Even though how environment acts as a stimuli has already been discussed, there is little known about the complete mix of characteristics of the servicescape, as mixing of numerous elements of servicescape increased the limited information base on the international outlines of servicescape (Kearney, 2007).

\section{Servicescape; a Driver to Customer Loyalty}

One of the most important elements of service marketing is service loyalty which is responsible of repurchasing of service by customers. Service quality influences service loyalty by means of customer satisfaction and different demographics such as age and education play a major role in defining altered opinions of customers (Caruana, 2002). Finding the link between the relationships between the two loyalty patterns (attitudinal and behavioral) of customer behavior is necessary because of its link with profitability, as the sustaining and developing of customer loyalty can be based on rewarding the customers who have different loyalty status (McMullan, 2005). Organizations should understand how service settings provoke emotional response which influences their customer's decisions regarding their association with a certain service provider. Therefore they should evaluate a range of servicescape variables and sensibly manage their impact on the degree to which consumer's nurture optimistic intents to be loyal (Harris \& Ezeh, 2008).

A perceived servicescape comprises several elements that are physical, social, symbolic and natural, which are not only objective, but are also meaningful for the target market and works as

stimuli to customer's approach/avoidance decisions and mostly their person-place attachment (Rosenbaum \& Massiah, 2011). The servicescape effects the overall service quality which in turn effects a consumer's behavior, as among price rationality and waiting experience, the latter is more influential to consumer interaction and therefore the customer waiting time should be minimized and if that is not possible, the restaurant manager should apply perception management methods so that the waiting time observed by customers is reduced, so that the perceived value services can be enhanced (Chen, 2011).

Service experience also influences a consumer's post-consumption evaluation apart from a customer's feelings, satisfaction and brand attitudes (Grace \&O'Cass, 2004). Consumers face multiple difficulties while choosing and consuming services as purchase decisions, consumption experiences and post-purchase evaluation are rather tricky for consumers. A steady competitive strategy has an influence on the strength of the association between customer satisfaction and servicescape features and the payoff for investment varies conditional to these competitive strategies (Miles, Miles, \&Cannon, 2012). The firm's strategies and operational decisions should be aligned to seek complete customer satisfaction, 
even though there is no comprehensible way of how the service's characteristics can be combined in a way to create an effective competitive strategy (Miles et al., 2012).

\section{RESEARCH METHODS}

\section{METHOD OF DATA COLLECTION}

Rather than focusing on one social class or segment, we gathered the data through a selfadministered survey to test the hypothesis from 308 respondents of upper, middle and lower classes on the probability based systematic random sampling technique. The research was conducted to gauge the impact of brand servicescape on consumers of Pakistan relative to social class.

\section{SAMPLING TECHNIQUE}

This research has been undertaken in the field of marketing under the limitations that the impact of servicescapes has been analyzed on the basis of social class with reference to Pakistani economy. The systematic random sampling technique has been applied for this purpose of data collection. A self-administered questionnaire was used to collect the data from the target population belonging to upper, lower and middle/working classes for this purpose of testing the assumptions.

\section{SAMPLE SIZE}

Keeping in mind the scope of this study the sample size of 308 respondents were selected, the difficulties with sampling the entire population have long been recognized so taking 308 respondents and generalizing them was necessary. Although it has been kept in mind that there must not be any over lapping in-terms of demographic characteristics of the target population, an analysis of the demographic situation with respect to gender are 60 percent males and 40 percent females. The age ranged from 25 to 50 years of the sample, lastly the income bracket also varied from 25000 to 75000 which clearly reflect the social class of the population.

\section{INSTRUMENT OF DATA COLLECTION}

To support the collection of firsthand information from the respondents a structured questionnaire was adopted, for assessing the loyalty the conceptual development of customer loyalty measurement scale proposed by McMullan (2005) was adapted and for gauging the servicescape of the restaurant's the instrument proposed by Hightower (2010) was adopted. The questionnaire was divided into 3 parts; in the $1^{\text {st }}$ part of the questionnaire 12 questions were aimed to get the insight about the servicescape which states the general perception about the physical environment including the design, ambience and social dimensions of the environment of restaurant. The $2^{\text {nd }}$ part of the questionnaire contained 15 questions aimed at understanding the loyalty status of the respondents. The $3^{\text {rd }}$ part of the questionnaire aimed at the demographics of the respondents such as age, gender, income status, name and contact details.

\section{RESEARCH MODEL DEVELOPED}

The research model consists of a logical link between the servicescape and the loyalty of the consumers. The research model represents the independent variable servicescape and its dimensions such as ambiance, social and design dimension and how these dimensions impact the dependent variable customer's loyalty, it also reflects how 
intermediating variable "social class" impacts the loyalty status of the consumers. After doing the literarure review in chaper 2 the following conceptual framework has been established. (See figure 1 in appedix)

\section{STATISTICAL TECHNIQUE}

Close ended questionnaire was used for the purpose of data analysis and the reliability of the questionnaire is checked by using SPSS and AMOS. Confirmatory factor analysis (CFA) and composite reliability test were applied to check the reliability of the instrument. Validity was checked by using convergent validity and discriminant validity test. Data was analyzed by using structural equation modeling (SEM) through AMOS 18. The fit of proposed model to the data was analyzed through structural regression model (SRM). Moderation effects were tested through 5000 Bootstrapping samples and moderation was analyzed by using orthogonalization. Moderation was tested with the help of SPSS MACRO developed by Preacher \& Hays.

\section{RESULTS}

\section{DATA SCREENING:}

The total data set comprised of 308 respondents. In the first instance, data collected screening was run. In this we checked missing values, aberrant values, multivariate outliers, homoscedasticity, and multicollinearity. There were no missing values in the data set as shown in the table below.(See Table 4.1 in appedix)

For testing our hypothesis, the requirement is multivariate data analysis techniques, which require the detection of multivariate outliers. So we used mahalanobis distant measuring method for detection of outliers. We removed the cases which had the probability of less than .001. In total 11 cases were removed. So our final data set comprised of 297 respondents.(See table 4.2 in appedix)

The data was not normal and exhibited the quasi normality.

\section{MEASUREMENT MODEL:}

All the measures used in survey instrument were selected from current research and they were well validated scales. For checking the validity of these measurement scales in our research context, we performed confirmatory factor analysis in AMOS 18. Following fit indices were also taken into consideration to assess model capability(Byrne, 2001), namely CMIN/df, Tucker-Lewis Index (TLI), Comparative Fit Index (CFI), and Root-Mean Square Error of Approximation (RMSEA). CFI and TLI values above 0.90 and RMSEA scores below 0.08 represent a good model fit (Hair, Black, Babin, \& Anderson, 2010). The first model (Model 0) included all the items used for measuring the four constructs, which are ambient, social, and design dimensions of servicecapes and customer loyalty(Kline, 2011). This model showed poor fit to data $(\mathrm{CMIN} / \mathrm{df}=3.30, \mathrm{CFI}=0.75$; TLI $=0.78, \mathrm{RMSEA}=$ 0.09). Then the items with low factor loadings were removed (a total of six items were removed (i.e., one for Ambient, one for Social, one for Design and two for Customer loyalty). The model fit statistics (for Model 1) were significantly improved to an acceptable level in the second model $(\mathrm{CMIN} / \mathrm{df}=2.98, \mathrm{CFI}=0.91$; $\mathrm{TLI}=0.90, \mathrm{RMSEA}=0.07)$. (See table 4.3 in appedix) (See figure 4.1 in appedix)

All the measures have exhibited acceptable level of reliability (i.e. Cronbach Alpha values). Such as Ambient $=0.71$, Social $=0.75$, Design $=0.72$, and Customer loyalty $=0.70$ ). 


\section{HYPOTHESIS TESTING:}

For testing of hypothesis, linear regression was used, after testing the basic assumptions in SPSS 18, all the hypothesis were tested one by one. For testing the moderation effects, we used Preacher and Hayes's Macro in SPSS called ModProbe. First hypothesis stated that ambient dimension of servicecapes has a positive impact on customer loyalty. This hypothesis was supported by the results of data analysis (i.e. $\beta=.276, p=.000$ ). (See table 4.4 in appedix)

The second hypothesis stated that social dimension of servicecapes has a positive impact on customer loyalty. This hypothesis was also supported by the results of data analysis (i.e. $\beta=$ $.215, \mathrm{p}=.000)$. (See table 4.5 in appedix)

The third hypothesis of the study stated that design dimension of servicecapes has a positive impact on customer loyalty. This hypothesis was rejected by the analysis results $(\beta=. .035, \mathrm{p}$ $=.545)$. (See table 4.6 in appedix $)$

Hypothesis 4, 5, and 6 were tested through Preacher and Hayes's macro. Hypothesis 4 stated that the relationship between ambiance of restaurant and customer loyalty is moderated by social class such that the relationship would be stronger for upper and middle classes as compared to lower class. Hypothesis 5 stated that the relationship between social dimension of restaurant and customer loyalty is moderated by social class such that the relationship would be stronger for upper and middle classes as compared to lower class. Hypothesis 6 stated that the relationship between design dimension of restaurant and customer loyalty is moderated by social class such that the relationship would be stronger for upper and middle classes as compared to lower class. None of the moderation hypotheses was supported by the result of the analysis as shown in the table below. (See table 4.7 in appedix)

\section{STATEMENT OF FALSIFICATION}

The statement of falsification for two accepted hypothesis are as follows:

H1: Ambiance of the restaurant has a positive impact on customer's loyalty.

Statement of falsification for H1: Ambiance of the restaurant has no positive impact on customer's loyalty if customer is blind.

H2: Social dimension of the restaurant has a positive impact on customer's loyalty.

Statement of falsification for H2: Social dimension of the restaurant has no positive impact on customer's loyalty if customer possesses an introvert (conservative personality).

\section{CONCLUSION, DISCUSSION, IMPLEMENTATIONSAND FUTURE RESEARCH CONCLUSION}

After the data was gathered and examined by using CFA all the measures have shown the acceptability such as Ambient $=0.71$, Social $=0.75$, Design $=0.72$, and Customer loyalty $=0.70$ ). Linear regression was used to test first three hypotheses which reflected that the ambience, social dimension and design dimension of servicescape has a positive relation with loyalty of a restaurant.

On the other hand, results of hypotheses 4,5 and 6 reflected the results that social class gives a great impact when selection of restaurant is the point of concern. Upper and middle classes are more concerned about the physical environment, design dimension and the social dimension of the servicescapes of the restaurant however, since lower classes are price sensitive they are anxious about the environment of the restaurant. 


\section{DISCUSSIONS}

This research has brought into the consideration the buying and the spending pattern of consumers in Pakistan and the factors that influence the selection of the restaurant. The influence of Ambience, Social dimension and the design dimension was positive on loyalty with respect to social class. The middle and upper classes are assessing the restaurants keeping in mind the physical environment of the place due to which they repeatedly select the same place again and again. However, lower classes are price sensitive customers and hence are not concerned about the servicescape which in their case has no impact on loyalty.

\section{IMPLICATION}

This study is helpful for education industry, marketing managers and marketing heads of hotel industry. It can help them in developing and improving the servicescapes of restaurants with respect to the social classes of Pakistani customers. It shows how marketing managers improve on physical facilities, architecture, physical environment and cleanliness of the restaurant in order to make customers loyal and keep them coming for the dining experience at their restaurant over and over again. The behavior can be influenced by continuously improving the servicescapes of restaurant.

\section{FUTURE RESEARCH}

Future research would spotlight the changing consumer behavior of Pakistani consumers because the personal factors, cultural factors and the social factors also impact the purchasing pattern of the target market. Therefore the collection of this data can be done through focus groups, and observational research methods to enhance the quality of results from different qualitative angles.

\section{REFERENCES}

Andaleeb, S.S., Conway, C., 2006. Customer satisfaction in the restaurant industry: an examination of the transaction-specific model. Journal of Services Marketing 20 (1), 3-11.

Anderson, E.W., Fornell, C., Lehmann, D.R., 1994. Customer satisfaction, market share, and profitability: findings from Sweden. Journal of Marketing 58 (3), 53-66.

Bitner, M. J. (1992). Servicescapes: The Impact of Physical Surrounding on Customers and Employees. Journal of Marketing, 56, 57-71.

Byrne, B. M. (2001). Structural equation modeling with AMOS: Basic concepts, application, and programming. Hillsdale, NJ: Lawrence Erlbaum.

Caruana, A. (2002). Service loyalty: The effects of service quality and the mediating role of customer Satisfaction. European Journal of Marketing, 36(7), 811 - 828.

Chang, K.-H., Cheng, C.-H. (2011). Evaluating the risk of failure using the fuzzy OWA and DEMATEL method. Journal of Intelligent Manufacturing 22(2): 113-129.

Ching, C., Cheng-T. , Fu, S., Hsiu, Y., 2012. Enhancing service quality improvement strategies of fine-dining restaurants: New insights from integrating a two-phase decision-making model of IPGA and DEMATEL analysis. International Journal of Hospitality Management, (in-press)

Chen, K. U. (2011). Effects of servicescape, waiting experiences and price rationality on consumers' behavioral intentions in scenery restaurants. African Journal of Business Management, 5(11), 4476-4484. 
Chen, P., \& Hu, H. (2010). How determinant attributes of service quality influence customer perceived value. International Journal of Contemporary Hospitality Management, 22(4), $535-551$.

Cobanoglu, C., Bilgihan, A., Nusair, K. K., \& Berezina, K. (2012).The Impact of Wi-Fi Service in Restaurants on Customers' Likelihood of Return to a Restaurant. Journal of Foodservice Business Research, 15(3), 285-299.

Coelho, P. S., \& Henseler, J. (2012). Creating customer loyalty through service customization. European Journal of Marketing, 46(3/4), 331 - 356.

Cronin, J. J., \& Taylor, S. A., 1992. Measuring service quality: A reexamination and extension. Journal of Marketing, 56, 55-68.

Gronroos, C. (1984). A service quality model and its marketing implications. European Journal of Marketing, 18(4), 36-44.

Grace, D., \&O'Cass, A. (2004).Examining service experiences and post-consumption evaluations. Journal of Services Marketing, 18(6), 450 - 461.

Grace, D., \&O'Cass, A. (2001). Attributions of service switching: a study of consumers' and providers' perceptions of child-care service deliver. Journal of Services Marketing, 15(4), 300-21.

Hair, J. F., Black, W. C., Babin, B. J., \& Anderson, R. E. (2010). Multivariate data analysis(7th ed.). Upper Saddle River, NJ: Prentice Hall.

Hansen, E., Bush, R.J., 1999. Understanding customer quality requirements. Industrial Marketing Management 28 (2), 119-130.

Han, H., \& Ryu, K., 2010. Influence of the Quality of Food, Service, and Physical Environment on Customer Satisfaction and Behavioral Intention in Quick-Casual Restaurants: Moderating Role of Perceived Price. Journal of Hospitality \& Tourism Research, 34(3), 310-329.

Harris, L. C., \& Goode, M. M. H. (2010).Online servicescapes, trust, and purchase intentions. Journal of Services Marketing, 24(3), 230 - 243.

Harris, L. C., \&Ezeh, C. (2008). Servicescape and loyalty intentions: an empirical investigation, European Journal of Marketing, 42(3), 390 - 422.

Hightower, Jr. R. (2010).Commentary on conceptualizing the servicescape construct in 'a study of the Service encounter in eight countries. The Marketing Management Journal, 20(1), 76-86.

Izogo, E. E., \& Ogba, I. (2015). Service quality, customer satisfaction and loyalty in automobile repair services sector. International Journal of Quality \& Reliability Management, 32(3), 250 - 269.

Johnstone, M. L. (2012). The servicescape: The social dimensions of place. Journal of Marketing Management, 28 (11-12), 1399-1418.

Jones, T., \& Taylor, S. F. (deceased), (2012). Service loyalty: accounting for social capital. Journal of Services Marketing, 26(1), 60 - 75.

Kearney, T., Kennedy, A., \& Coughlan, J. (2007). Servicescapes: A Review of Contemporary Empirical Research. Sixteenth Annual Frontiers in Service Conference, San Francisco, CA.

Kline, R. B. (2011). Principles and practice of structural equation modeling (3rd ed.). New York: Guilford Press.

Kursunluoglu, E. (2014). Shopping centre customer service: creating customer satisfaction and loyalty. Marketing Intelligence \& Planning, 32(4), 528 - 548.

Koul, S., \& Mishra, H. G. (2013). Customer Perceptions for Store Attributes: A Study of Traditional Retail Stores In India. Journal of Business \& Economics, 5(1), 79-103. 
Lin, W.-R., Wang, Y.-H., Hung, Z.-E. (2012). Selecting mobile banking system service for consumers by using a combined DEMATEL and ANP approach, Journal of Accounting, Finance \& Management Strategy 7(1): 1-14.

Lin, I. Y., \&Mattila, A. S. (2010).Restaurant Servicescape, Service Encounter, and Perceived Congruency on Customers' Emotions and Satisfaction. Journal of Hospitality Marketing \& Management, 19(8), 819-841.

Liou, J.J.H., Tzeng, G.H., Chang, H.C. (2007). Airline safety measurement using a hybrid model. Journal of Air Transport Management 13: 243-249.

Mari, M. \&Poggesi, S. (2013). Servicescape cues and customer behavior: A systematic literature review and research agenda. The Service Industries Journal, 33(2), 171-199.

Marr, J.W., 1986. Letting the customer be the judge of quality. Quality Progress 19 (10), 4649.

Mathews, S. J., Bonn, M. A., \& Snepenger, D. (2009). Atmospherics and consumers' symbolic interpretations of hedonic services. International Journal of Culture, Tourism and Hospitality Research, 3(3), 193 - 210.

McMullan, R. (2005). A multiple-item scale for measuring customer loyalty development. Journal of Services Marketing, 19(7), 470 - 481.

Miles, P., Miles, G., Cannon, A. (2012). Linking servicescape to customer satisfaction: exploring the role of competitive strategy. International Journal of Operations \& Production Management, 32(7), 772 - 795.

Normann, R. (1991). Service Management, Strategy and Leadership in Service Business. John Wiley \& Sons: Chichester, UK.

Parasuraman, A., Zeithaml, V.A. and Berry, L.L., 1985, "A conceptual model of service quality and implications for future research", Journal of Marketing, Vol. 49, Fall, pp. 41-50

Reimer, A., \& Kuehn, R. (2005).The impact of servicescape on quality perception. European Journal of Marketing, 39(7), 785 - 808.

Rosenbaum, M. S., Massiah, C. (2011). An expanded servicescape perspective. Journal of Service Management, 22(4), 471 - 490.

Shin, D., \& Elliott, K. (2001).Measuring customers' overall satisfaction: a multi-attributes assessment. Services Marketing Quarterly, 22(1), 3-19.

Shieh, J.-I, Wu, H.-H., Huang, K.K. (2010). A case of applying DEMATEL method in identifying key success factors of hospital service quality. Knowledge-Based Systems 23(3): 277-282.

Siddiqui, M. H., \& Tripathi, S. N. (2011).Application of Soft Operations Research for Enhancing the Servicescape as a Facilitator.Vikalpa: The Journal for Decision Makers, 36(1), 36-49.

Tsai, W.-H., Chou, Y.-W., Lee, K.-C., Lin, W.-R., Hwang, E.T.Y. (2013). Combining decision making trial and evaluation laboratory with analytic network process to perform an investigation of information technology auditing and risk control in an enterprise resource planning environment. Systems Research and Behavioral Science 30(2): 176-193.

Tzeng, G..H., Chiang, C.H., Li, C.W. (2007). Evaluating intertwined effects in e-learning programs: a novel hybrid MCDM model based on factor analysis and DEMATEL. Expert Systems with Applications 32: 1028-1044.

Uhrich, S., \& Benkenstein, M. (2011). Physical and social atmospheric effects in hedonic service consumption: customers' roles at sporting events. The Service Industries Journal, 32(11), 1741-1757 
Wall, E. A., \& Berry, L. L. (2007).The Combined Effects of the Physical Environment and Employee Behavior on Customer Perception of Restaurant Service Quality. Cornell Hotel and Restaurant Administration Quarterly, 48(1), 59-69.

Walter, U. (2008). The meeting aspect and the physical setting: are they important for the guest experience?. Journal of Foodservice, 19, 87-95.

Walter, U., \& Edvardsson, B. (2012). The physical environment as a driver of customers' service experiences at restaurants. International Journal of Quality and Service Sciences, 4(2), $104-119$.

Walter, U., Edvardsson, B., \& Ostrom, A. (2010). Drivers of customer's service experiences: a study in the restaurant industry. Managing Service Quality, 20(3), 236-258.

Williams, T. G. (2002). Social class influences on purchase evaluation criteria. Journal of Consumer Marketing, 19(3), 249 - 276.

Wu, H.-H., Chen, H.K., Shieh, J.-I (2010). Evaluating performance criteria of employment service outreach program personnel by DEMATEL method. Expert Systems with Applications 37(7): 5219-5223.

Yavetz, V, I., \&Gilboa, S. (2010). The Effect of Servicescape Cleanliness on Customer Reactions. Services Marketing Quarterly, 3(2), 213-234.

Zhou, Q., Huang, W., Zhang, Y. (2011), Identifying critical success factors in emergency management using a fuzzy DEMATEL method. Safety Science 49(2): 243-252.

\section{APPEDIX}

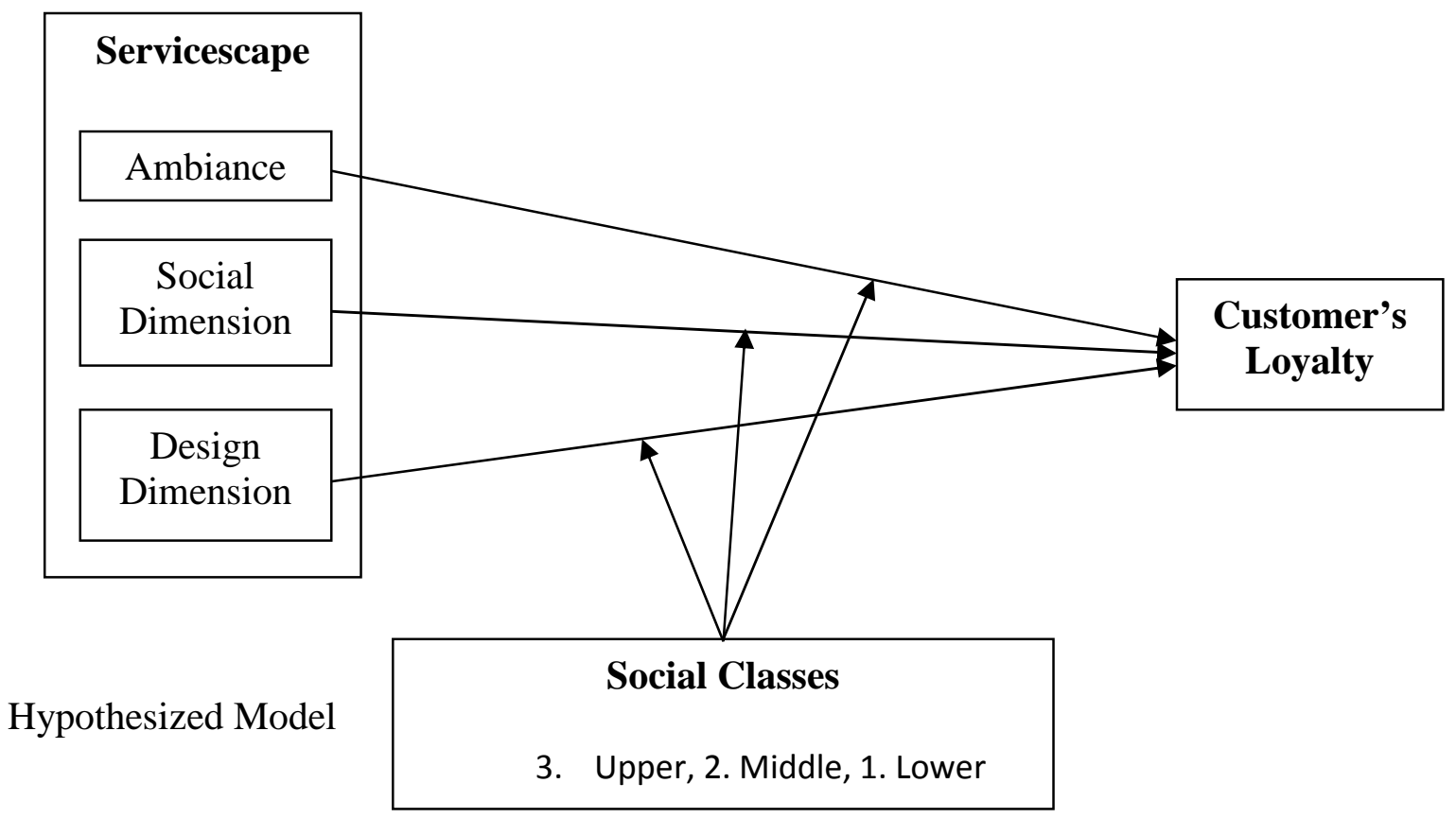




\begin{tabular}{|c|c|c|c|c|c|}
\hline \multicolumn{6}{|c|}{ Table 4.1 Missing Values } \\
\hline & $\mathrm{N}$ & Mean & $\begin{array}{l}\text { Std. } \\
\text { Deviation }\end{array}$ & Missil & \\
\hline & Count & Percent & Low & High & Count \\
\hline Q2_Ambient_Dimension & 308 & 4.0519 & .72455 & 0 & .0 \\
\hline Q3_Ambient_Dimension & 308 & 3.8247 & .74966 & 0 & .0 \\
\hline Q4_Ambient_Dimension & 308 & 3.8506 & .77655 & 0 & .0 \\
\hline Q5_Social_Dimension & 308 & 3.8799 & .88151 & 0 & .0 \\
\hline Q6_Social_Dimension & 308 & 3.6851 & .96595 & 0 & .0 \\
\hline Q7_Social_Dimension & 308 & 3.2630 & 1.00438 & 0 & .0 \\
\hline Q8_Social_Dimension & 308 & 3.2987 & .95930 & 0 & .0 \\
\hline Q9_Design_Dimension & 308 & 3.8409 & .83335 & 0 & .0 \\
\hline Q10_Design_Dimension & 308 & 3.8539 & .83962 & 0 & .0 \\
\hline Q11_Design_Dimension & 308 & 3.8604 & .73311 & 0 & .0 \\
\hline Q12_Design_Dimension & 308 & 3.6494 & .95524 & 0 & .0 \\
\hline QL1_Loyalty & 308 & 3.6299 & .89115 & 0 & .0 \\
\hline QL2_Loyalty & 308 & 3.2857 & .97335 & 0 & .0 \\
\hline QL3_Loyalty & 308 & 3.5552 & .92744 & 0 & .0 \\
\hline QL4_Loyalty & 308 & 3.2825 & 1.02481 & 0 & .0 \\
\hline QL5_Loyalty & 308 & 3.4545 & .95222 & 0 & .0 \\
\hline
\end{tabular}

\begin{tabular}{|l|l|}
\hline \multicolumn{2}{|c|}{ Table: $\begin{array}{c}\text { 4.2Mahalanobis Distance } \\
\text { Probability }\end{array}$} \\
\hline Sr. No & $\begin{array}{l}\text { Mahalanobis } \\
\text { Probability }\end{array}$ \\
\hline 1 & .0000 \\
\hline 2 & .0000 \\
\hline 3 & .0000 \\
\hline 4 & .0000 \\
\hline 5 & .0000 \\
\hline 6 & .0000 \\
\hline 7 & .0002 \\
\hline 8 & .0002 \\
\hline 9 & .0003 \\
\hline 10 & .0003 \\
\hline 11 & .0004 \\
\hline
\end{tabular}

\begin{tabular}{|l|l|l|l|l|l|}
\hline \multicolumn{9}{|c|}{ Table 4.3 Result of CFA } \\
\hline Model & Description & CMIN/df & TLI & CFI & RMSEA \\
\hline Model 0 & With all the items of four constructs & 3.30 & .78 & .75 & .09 \\
\hline Model 1 & With reduced items & 2.98 & .91 & .90 & .07 \\
\hline
\end{tabular}


Figure 4.1 CFA Diagram

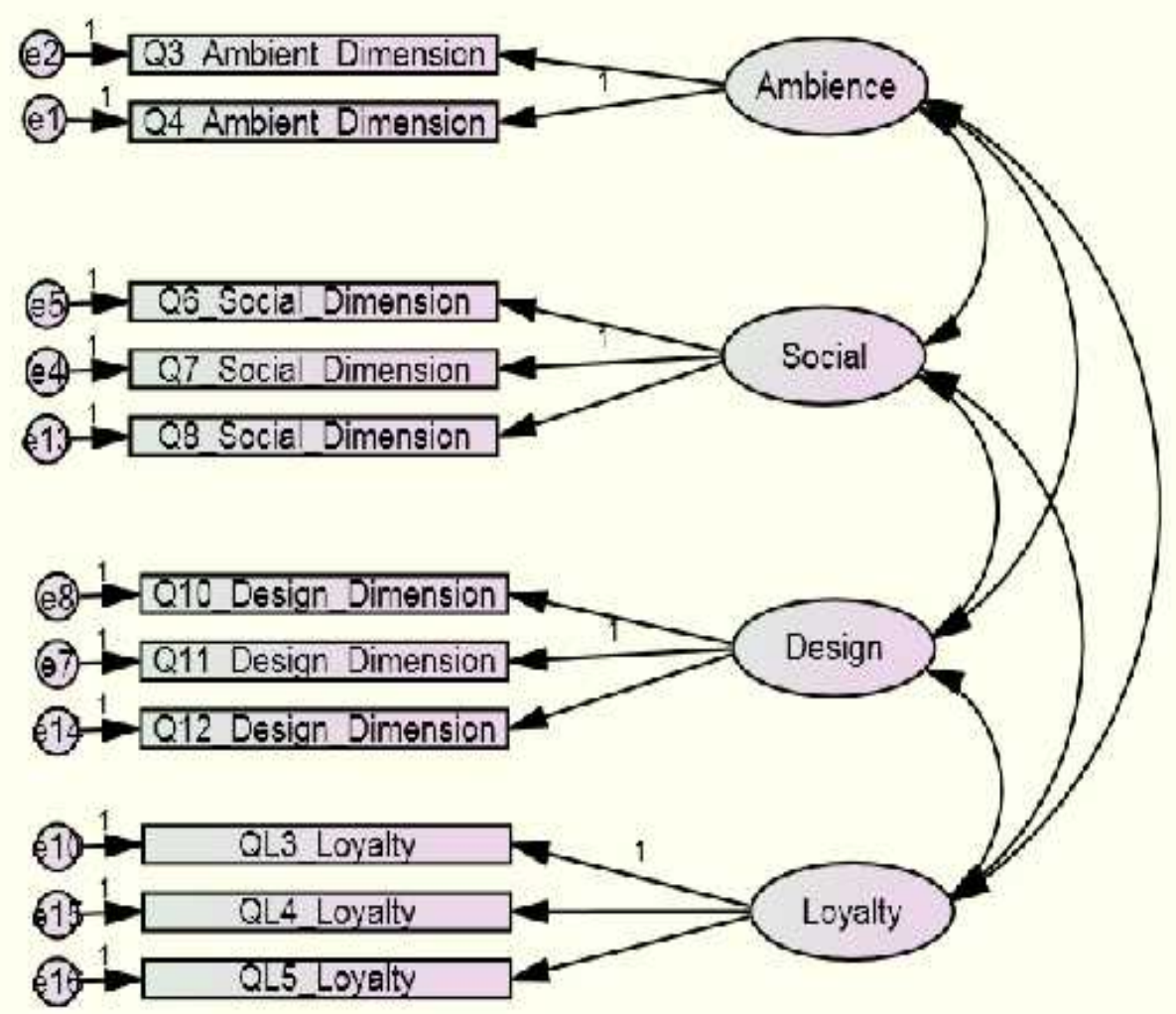

\begin{tabular}{|l|l|l|l|l|l|l|}
\hline \multicolumn{7}{|c|}{ Table: 4.4 Coefficients(a) } \\
\hline Model & & $\begin{array}{l}\text { Unstandardized } \\
\text { Coefficients }\end{array}$ & $\begin{array}{l}\text { Standardized } \\
\text { Coefficients }\end{array}$ & T & Sig. \\
\cline { 3 - 8 } & & B & Std. Error & Beta & B & $\begin{array}{l}\text { Std. } \\
\text { Error }\end{array}$ \\
\hline 1 & Constant) & 2.225 & .247 & & 8.993 & .000 \\
\cline { 2 - 8 } & Ambient_mean & .313 & .063 & .276 & 4.926 & .000 \\
\hline
\end{tabular}

Table: 4.4

a) Dependent Variable: Loyalty_mean

\begin{tabular}{|l|l|l|l|l|l|l|}
\hline \multicolumn{7}{|c|}{ Table: 4.5 Coefficients(a) } \\
\hline Model & & $\begin{array}{l}\text { Unstandardized } \\
\text { Coefficients }\end{array}$ & $\begin{array}{l}\text { Standardized } \\
\text { Coefficients }\end{array}$ & T & Sig. \\
\cline { 3 - 8 } & & B & Std. Error & Beta & B & Std. Error \\
\hline 1 & (Constant) & 2.754 & .182 & & 15.094 & .000 \\
\cline { 2 - 7 } & Social_mean & .196 & .052 & .215 & 3.787 & .000 \\
\hline
\end{tabular}

a) Dependent Variable: Loyalty_mean 


\begin{tabular}{|l|l|l|l|l|l|l|}
\hline \multicolumn{7}{|c|}{ Table: 4.6 Coefficients (a) } \\
\hline Model & & $\begin{array}{l}\text { Unstandardized } \\
\text { Coefficients }\end{array}$ & $\begin{array}{l}\text { Standardized } \\
\text { Coefficients }\end{array}$ & T & Sig. \\
\cline { 3 - 8 } & & B & Std. Error & Beta & B & Std. Error \\
\hline 1 & Constant) & 3.277 & .252 & & 12.987 & .000 \\
\cline { 2 - 8 } & Design_mean & .040 & .065 & .035 & .606 & .545 \\
\hline
\end{tabular}

a) Dependent Variable: Loyalty_mean

\begin{tabular}{|l|l|l|l|}
\hline \multicolumn{4}{|c|}{ Table: 4.7 Moderation Results of Macro } \\
\hline Hypothesis & $\begin{array}{l}\text { R Square Change due to } \\
\text { Interaction }\end{array}$ & $\mathbf{F}$ & $\mathbf{P}$ \\
\hline H 4 & .0002 & .0478 & .8270 \\
\hline H 5 & .0003 & .0791 & .7787 \\
\hline H 6 & .0001 & .0439 & .8343 \\
\hline
\end{tabular}

